\title{
Improved SIFTER v2 algorithm for long-term GOME-2A satellite retrievals of fluorescence with a correction for instrument degradation
}

Erik van Schaik et al.

Correspondence to: K. Folkert Boersma (folkert.boersma@wur.nl)

The copyright of individual parts of the supplement might differ from the CC BY 4.0 License. 


\section{GOME-2A level-1b data}

Table S1. Level-1 data for GOME-2A used in this work.

\begin{tabular}{|c|c|c|c|}
\hline Period & $\begin{array}{l}\text { Level-1b } \\
\text { processor } \\
\text { version } \\
\end{array}$ & Main issue & Reference \\
\hline $\begin{array}{l}\text { Until } 17 \text { May } \\
2014\end{array}$ & 5.3 & $\begin{array}{l}\text { All available level-1b data up to this date } \\
\text { calibrated with this processor }\end{array}$ & $\begin{array}{l}\text { Newsletter \#29 } \\
\text { [EUMETSAT, } \\
\text { 2015] }\end{array}$ \\
\hline $\begin{array}{l}18 \text { May } 2014 \\
-25 \text { June } \\
2015\end{array}$ & 6.0 & $\begin{array}{l}\text { Provision of additional cloud information } \\
\text { from the AVHRR cloud mask on PMD read- } \\
\text { out level. }\end{array}$ & $\begin{array}{l}\text { Newsletter \#35 } \\
\text { [EUMETSAT, } \\
\text { 2015] }\end{array}$ \\
\hline $\begin{array}{l}\text { 26 June } 2015 \\
-11 \text { January } \\
2018\end{array}$ & 6.1 & $\begin{array}{l}\text { Introduction of in-flight derived BSDF for } \\
\text { solar radiometric calibration affecting the } \\
\text { solar irradiance data. May have resulted in } \\
\text { changes of the radiometric accuracy to } \\
\text { unknown extent. }\end{array}$ & $\begin{array}{l}\text { Newsletter \#36 } \\
\text { [EUMETSAT, } \\
\text { 2015] }\end{array}$ \\
\hline $\begin{array}{l}12 \text { January } \\
2018-17 \\
\text { December } \\
2018\end{array}$ & 6.2 & $\begin{array}{l}\text { Implementation of the solar model for the } \\
\text { solar visibility gaps. Visibility gaps are due } \\
\text { to the instrument drift and will recur in the } \\
\text { future. }\end{array}$ & \\
\hline
\end{tabular}

\section{Comparison of PCs from GOME-2A and DISAMAR}

We compared PCs obtained from the DISAMAR and GOME-2A spectra, and found that the two most relevant PCs (1: the mean, 2: dominated by water vapour absorption in 715-745 $\mathrm{nm}$ ), are highly similar between DISAMAR and GOME-2A (Figure S1). Higher-order PCs show stronger differences, probably related to fundamental differences between the simulations (cloud-free, no noise) and observations (mostly cloud-free, with cloud fractions up to $0.4^{1}$ ), and to other small differences in spectral behavior such as unaccounted atmospheric absorption signatures, surface effects, or instrumental features such as changes in the instrument transfer function, wavelength calibration etc.

\footnotetext{
${ }^{1}$ We select pixels over the Sahara with cloud fraction up to 0.4 here to ensure a sufficiently large and representative data sample, and to be consistent with the sampling approach followed for generating PCs in the operational retrieval (Section 4, Table 2).
} 


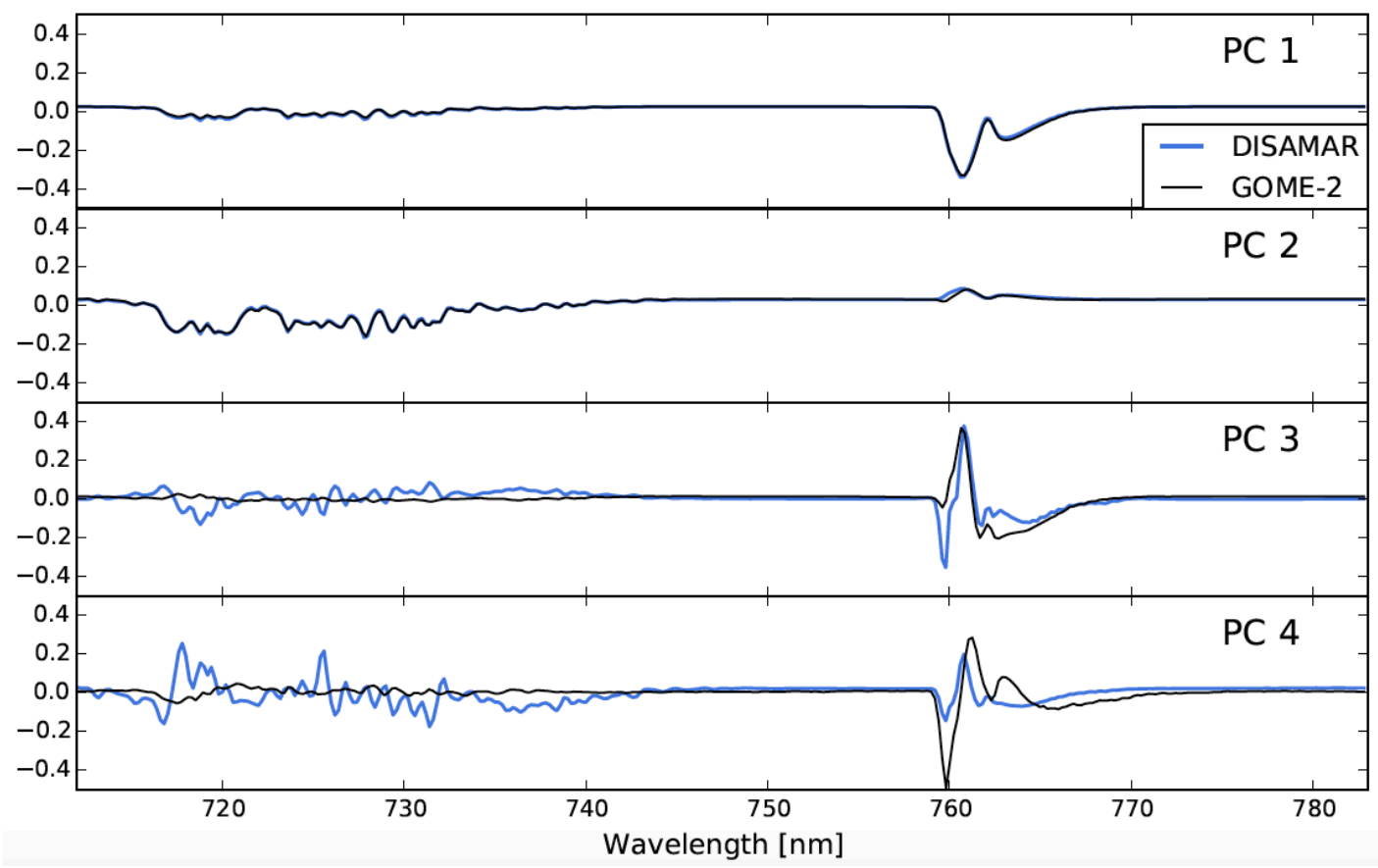

Figure S1. First four principal components (PCs) calculated for one year of TOA spectra measurements above the Sahara from GOME-2A (black, $n \approx 30,000$ ) and generated by DISAMAR (blue, $n=2000$ ). The y-axis is dimensionless.

\section{Spectral autocorrelation}

The degree of spectral lag-one autocorrelation in the fitting residuals has a strong relationship with the bias between the retrieved fluorescence and the a priori ('true') fluorescence strength used in the DISAMAR simulation. The lag-one autocorrelation coefficient $\left(r_{1}\right)$ to detect nonrandomness in the fit residuals $\left(y_{i}\right)$ is calculated as:

$$
r_{1}=\frac{\sum_{i=1}^{N-1}\left(y_{i}-\bar{y}\right)\left(y_{i+1}-\bar{y}\right)}{\sum_{i=1}^{N}\left(y_{i}-\bar{y}\right)^{2}}
$$

Figure S1 shows the results of a test to reproduce the input fluorescence strength of $4.0 \mathrm{~mW}$ $\mathrm{m}^{-2} \mathrm{sr}^{-1} \mathrm{~nm}^{-1}$ for an ensemble of DISAMAR spectra. The figure shows that the retrieved fluorescence strength and uncertainty strongly deviate when the autocorrelation coefficient exceeds 0.2 . 


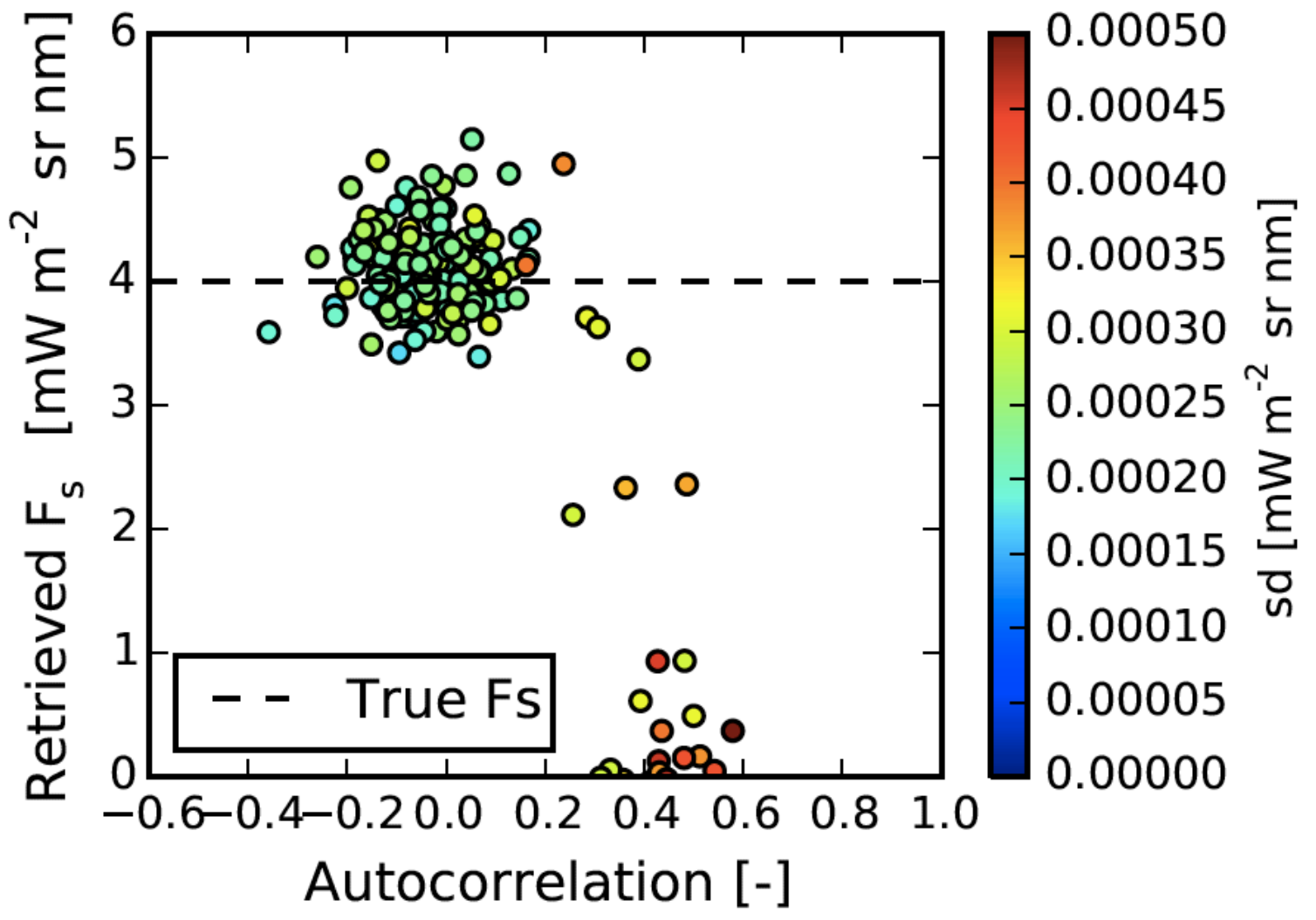

Figure S2. Retrieved fluorescence (734-758 nm, 8 PCs) as a function of autocorrelation in the fitting residuals for 200 TOA spectra simulated with DISAMAR. The colours of the circles indicate the uncertainty in the fit.

\section{Results of DISAMAR end-to-end experiments}

Table S2 below summarizes the results of the end-to-end experiments with different spectral fitting windows and PCs used for viewing geometries as over the Sahara, but much higher water vapour columns $\left(30-65 \mathrm{~g} \mathrm{~m}^{-2}\right)$. 
Table S2. Results of the 'Water' experiment (mean of 1,000 spectra) to reproduce fluorescence for different fitting windows and number of PCs used. The bias is defined here as the mean of the differences between assumed and retrieved fluorescence strength (which on average was $1.5 \mathrm{~mW} \mathrm{~m}^{-2} \mathrm{sr}^{-1} \mathrm{~nm}^{-1}$ ), and the RMSE stands for the root of the mean of the squared deviations. Faulty retrievals were not included in the calculation of the bias or the RMSE. 'Faulty' retrievals are characterized by high spectral autocorrelation $(>0.2)$ in their fit residuals.

\begin{tabular}{|c|c|c|c|c|}
\hline & Number of PCs & $\begin{array}{l}\text { Bias } \\
\left(\mathrm{mW} \mathrm{m}^{-2} \mathrm{sr}^{-1}\right. \\
\left.\mathrm{nm}^{-1}\right)\end{array}$ & $\begin{array}{l}\text { RMSE } \\
\left(\mathrm{mW} \mathrm{m}^{-2} \mathrm{sr}^{-1}\right. \\
\left.\mathrm{nm}^{-1}\right)\end{array}$ & Faulty \\
\hline \multirow{3}{*}{$\begin{array}{l}\text { 712-783 nm } \\
\text { (SIFTER v1) }\end{array}$} & 8 & -0.44 & 0.66 & $68.3 \%$ \\
\hline & 20 & -0.53 & 1.59 & $38.3 \%$ \\
\hline & 35 & -0.52 & 0.75 & $33.7 \%$ \\
\hline \multirow{3}{*}{$\begin{array}{l}712-758 \mathrm{~nm} \\
\text { (exclude O2-A) }\end{array}$} & 8 & -0.34 & 0.57 & $67.1 \%$ \\
\hline & 20 & -0.52 & 0.65 & $48.5 \%$ \\
\hline & 35 & -0.52 & 0.79 & $29.6 \%$ \\
\hline \multirow{3}{*}{$\begin{array}{l}734-783 \mathrm{~nm} \\
\text { (exclude } \mathrm{H}_{2} \mathrm{O} \\
\text { band) }\end{array}$} & 8 & -0.41 & 0.67 & $47.9 \%$ \\
\hline & 20 & -0.28 & 1.73 & $47.7 \%$ \\
\hline & 35 & -0.19 & 0.52 & $39.4 \%$ \\
\hline \multirow{3}{*}{$\begin{array}{l}734-758 \mathrm{~nm} \\
\text { (exclude both } \\
\text { bands) }\end{array}$} & 8 & +0.12 & 0.42 & $64.5 \%$ \\
\hline & 20 & +0.37 & 0.62 & $58.7 \%$ \\
\hline & 35 & +0.07 & 0.52 & $43.4 \%$ \\
\hline
\end{tabular}




\section{Trend in zero-level adjustment}

Figure S3 (left panel) shows the result of annual mean zero-level adjustments calculated from daily zero-level adjustments over the Pacific reference region $\left(130^{\circ}-150^{\circ} \mathrm{W}\right)$. There is no strong trend in the zero-level or a particular direction, and the zero-level adjustments agree to within $0.1 \mathrm{~mW} \mathrm{~m}^{-2} \mathrm{sr}^{-1} \mathrm{~nm}^{-1}$ for most latitudes. The right panel shows the linear fit of SIF against radiances of all pixels with cloud fractions $<0.4$ at $45^{\circ} \mathrm{N}$ in July 2007. The weak relationship that suggests a more prominent non-zero bias for high radiance levels, i.e. when Fraunhofer lines are relatively well-defined. The mean bias at $45^{\circ} \mathrm{N}$ based on all pixels is $0.095 \mathrm{~mW} \mathrm{~m}^{-2} \mathrm{sr}^{-1} \mathrm{~nm}^{-1}$ and the median value is $-0.088 \mathrm{~mW} \mathrm{~m}^{-2} \mathrm{sr}^{-1} \mathrm{~nm}^{-1}$. Binned mean SIF values with intervals of $0.1 \times 10^{13}$ photons $\mathrm{cm}^{-2} \mathrm{~s}^{-1} \mathrm{sr}^{-1} \mathrm{~nm}^{-1}$ are shown as light green squares. The linear regression through all data (grey circles) follows the binned values quite well, suggesting that a linear fit is reasonable.
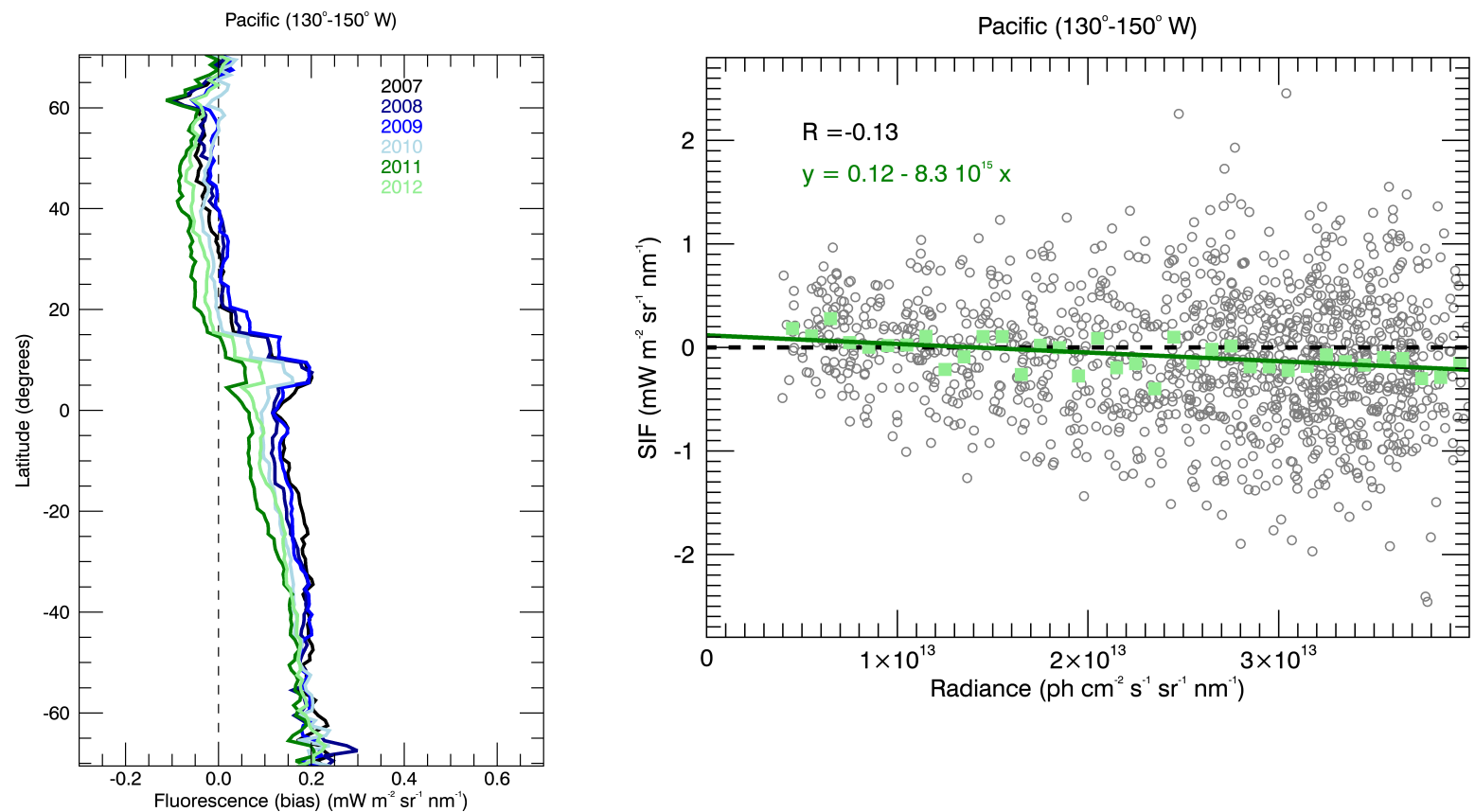

Figure S3. Left: Annual mean zero-level adjustment estimates determined over the Pacific Ocean reference sector $\left(130^{\circ}-150^{\circ} \mathrm{W}\right)$ for the years $2007-2012$ as a function of latitude. Right: SIF over the Pacific sector against radiances of all pixels with cloud fractions $<0.4$ that have been observed at $45^{\circ} \mathrm{N}$ in July 2007.

\section{Comparison of SIFTER v1 and SIFTERv2}

We examined the agreement of the monthly mean SIF between the new SIFTER v2 and previous SIFTER v1 product for six vegetated regions across the globe. Within these regions, the two products agree to within $0.3 \mathrm{~mW} \mathrm{~m}^{-2} \mathrm{~nm}^{-1} \mathrm{sr}^{-1}$. Both data products capture the seasonality of SIF, but SIFTER v2 returns signals that are substantially above zero in the NH 
winter. SIFTER v2 peak SIF values are higher than those from SIFTER v1 in the growing seasons.

Table S3. Monthly mean gridded SIF values retrieved from GOME-2A with SIFTER v2 and NASA v2.8 for different vegetated regions throughout the world in January and July 2011.

\begin{tabular}{|l|l|l|l|l|l|l|}
\hline & \multicolumn{3}{|c|}{ January 2011 } & \multicolumn{3}{c|}{ July 2011 } \\
\hline & $\begin{array}{l}\text { SIFTER } \\
\mathrm{v} 2 \\
\left(\mathrm{~mW} \mathrm{~m}^{-2}\right. \\
\left.\mathrm{nm}^{-1} \mathrm{sr}^{-1}\right)\end{array}$ & $\begin{array}{l}\text { SIFTER } \\
\mathrm{v} 1(\mathrm{~mW} \\
\mathrm{m}^{-2} \mathrm{~nm}^{-1} \\
\left.\mathrm{sr}^{-1}\right)\end{array}$ & $\begin{array}{l}\text { Relative } \\
\text { difference }\end{array}$ & $\begin{array}{l}\text { SIFTER } \\
\mathrm{v} 2(\mathrm{~mW} \\
\mathrm{m}^{-2} \mathrm{~nm}^{-1} \\
\left.\mathrm{sr}^{-1}\right)\end{array}$ & $\begin{array}{l}\text { SIFTER } \\
\text { v1 }(\mathrm{mW} \\
\mathrm{m}^{-2} \mathrm{~nm}^{-1} \\
\left.\mathrm{sr}^{-1}\right)\end{array}$ & $\begin{array}{l}\text { Relative } \\
\text { difference }\end{array}$ \\
\hline $\begin{array}{l}\text { Amazon }\left(70^{\circ}-\right. \\
\left.55^{\circ} \mathrm{W} ; 0^{\circ}-15^{\circ} \mathrm{S}\right)\end{array}$ & 1.47 & 1.20 & $+23 \%$ & 0.83 & 0.86 & $-4 \%$ \\
\hline $\begin{array}{l}\text { Sub-Saharan } \\
\text { Africa }\left(10^{\circ} \mathrm{W}-\right. \\
\left.30^{\circ} \mathrm{E} ; 5^{\circ}-10^{\circ} \mathrm{N}\right)\end{array}$ & 0.21 & 0.51 & $-59 \%$ & 0.91 & 0.90 & $+2 \%$ \\
\hline $\begin{array}{l}\text { Kalimantan } \\
\left(110^{\circ} \mathrm{E}-115^{\circ} \mathrm{E} ;\right. \\
\left.4^{\circ} \mathrm{S}-6^{\circ} \mathrm{N}\right)\end{array}$ & 0.76 & 0.65 & $+17 \%$ & 0.49 & 0.47 & $+4 \%$ \\
\hline $\begin{array}{l}\text { United States } \\
\text { Cornbelt }\left(96^{\circ} \mathrm{W}-\right. \\
81^{\circ} \mathrm{W} ; 38^{\circ} \mathrm{N}- \\
\left.46^{\circ} \mathrm{N}\right)\end{array}$ & -0.09 & 0.20 & N.A. & 1.57 & 1.38 & $+14 \%$ \\
\hline $\begin{array}{l}\mathrm{Western} \text { Europe } \\
\left(2^{\circ} \mathrm{W}-15^{\circ} \mathrm{N} ;\right. \\
\left.44^{\circ} \mathrm{N}-52^{\circ} \mathrm{N}\right)\end{array}$ & 0.07 & 0.32 & N.A. & 0.78 & 1.05 & $-26 \%$ \\
\hline $\begin{array}{l}\text { Southeastern } \\
\mathrm{China}\left(100^{\circ} \mathrm{E}-\right.\end{array}$ & 0.04 & 0.32 & N.A. & 1.10 & 1.13 & $-3 \%$ \\
$\begin{array}{l}120^{\circ} \mathrm{E} ; 25^{\circ} \mathrm{N}- \\
\left.35^{\circ} \mathrm{N}\right)\end{array}$ & & & & & & \\
\hline
\end{tabular}



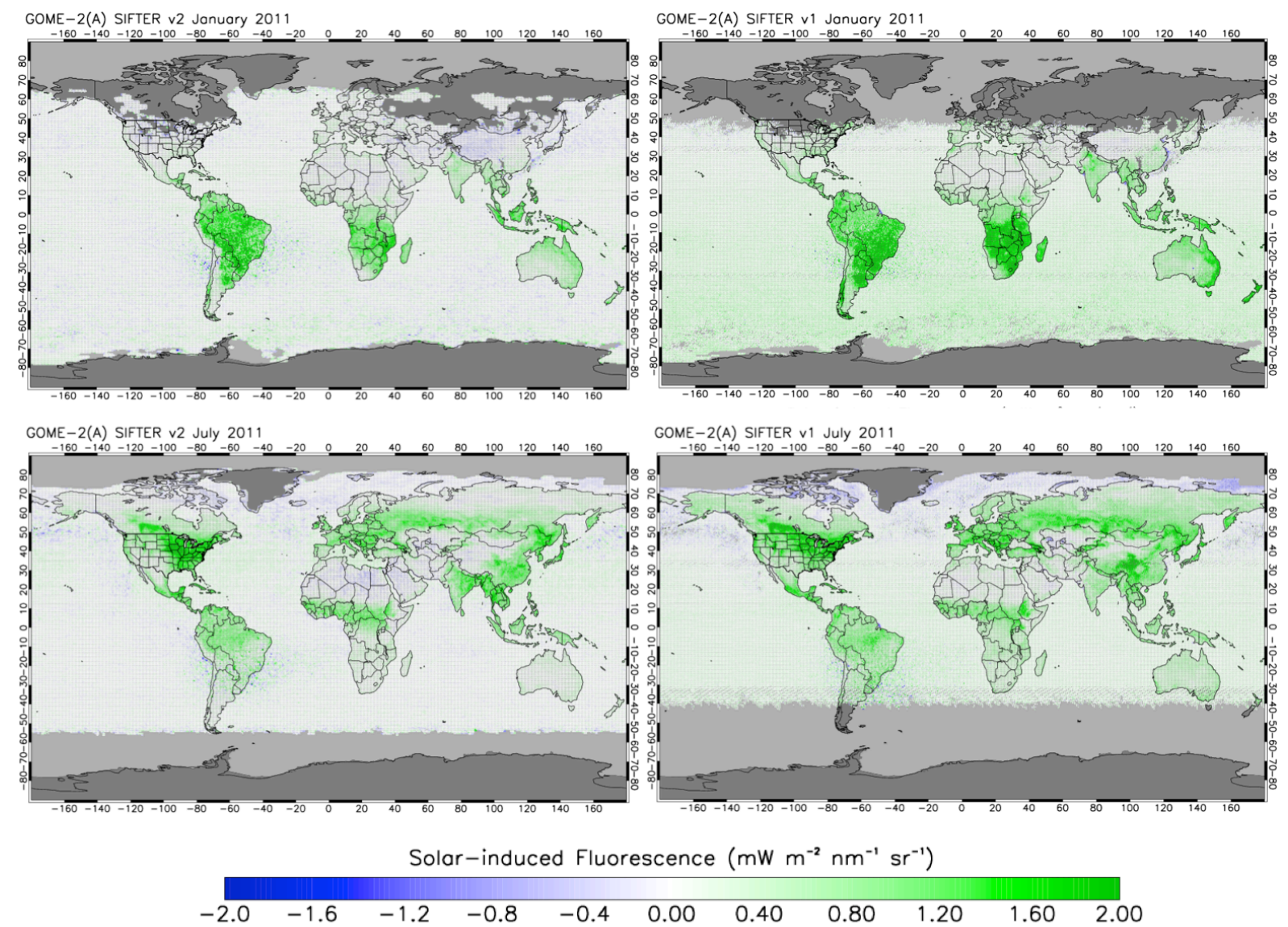

Figure S4. Gridded monthly mean SIF values retrieved from GOME-2A with SIFTER v2 (left panels) and SIFTER v1 (right) for January (upper panels) and July 2011 (lower panels). SIFTER v2 data has been selected for autocorrelation $<0.2$ and cloud fraction $<0.4$, SIFTER v1 data has been selected for solar zenith angles $<70^{\circ}$, RMS residuals $<1 \%$, and cloud fraction $<0.4$.

\section{References}

EUMETSAT: GOME-2 Newsletter Archive, EUM/OPSEPS/TEN/09/0552, v4C, Darmstadt, Germany, 139 pp., 2015. 